\title{
UPAYA PENINGKATAN HASIL BELAJAR DENGAN MENERAPKAN MODEL DISCOVERY LEARNING MELALUI LEARNING MANAGEMENT SYSTEM BERBASIS MOODLE
}

Oleh:

Neni Setyaningsih ${ }^{1}$

\begin{abstract}
Abstrak
Penelitian ini dilatarbelakangi oleh kurang aktifnya peserta didik saat pembelajaran jarak jauh dan kemampuan berpikir kritis yang rendah sehingga menyebabkan hasil belajar peserta didik tidak sesuai target. Penelitian ini bertujuan untuk mendeskripsikan data mengenai peningkatan hasil belajar belajar peserta didik setelah menerapkan model discovery learning melalui Learning Management System berbasis moodle. Penelitian ini dilakukan dengan subjek penelitian kepada peserta didik kelas XII IPS 3 di SMAIT Nur Hidayah Sukoharjo sebanyak 26 siswi. Metode yang digunakan adalah Penelitian Tindakan Kelas (PTK) dengan desain penelitian menggunakan Kemmis dan Mac. Taggart yang terdiri dari tahap perencanaan, pelaksanaan, observasi dan refleksi. Teknik pengumpulan data dengan menggunakan wawancara, observasi, catatan lapangan dan tes. Hasil penelitian ini menunjukkan ketuntasan pra siklus melalui hasil Penilaian Tengah Semester Gasal adalah 46\%. Setelah dilakukan tindakan terjadi peningkatan pada siklus I dan siklus II yaitu siklus I (69\%) dan siklus II (85\%). Kesimpulan dari penelitian ini adalah dengan menerapkan model discovery learning melalui Learning Management System berbasis moodle dapat meningkatkan hasil belajar peserta didik kelas XII IPS 3 SMAIT Nur Hidayah Sukoharjo.
\end{abstract}

Kata Kunci: Discovery Learning, Hasil belajar, Learning Management System, Moodle

\footnotetext{
${ }^{1}$ Guru Sosiologi SMAIT Nur Hidayah Sukoharjo, email : nenis8186@gmail.com
} 


\section{PENDAHULUAN}

Dalam pembangunan berbangsa, gender merupakan suatu strategi global yang berupaya untuk meningkatkan kepedulian akan aspirasi, kepentingan dan peranan perempuan dan laki-laki tanpa mengesampingkan harkat, kodrat dan martabat perempuan dan laki-laki dalam segala bidang. Proses pembangunan dan pengembangan manusia Indonesia melalui pendidikan tidak hanya terfokus kepada aspek pengetahuan dan intelektual anak, tetapi juga pembangunan dari aspek agama dan moral (akhlak). Dengan demikian pengembangan aspek-aspek tersebut diharapkan dapat terwujud manusia Indonesia seutuhnya. Artinya mereka menguasai tidak hanya ilmu pengetahuan dan teknologi tetapi juga menguasai sikap moral, mental dan spiritual yang baik pula.

Di Indonesia secara normative, Negara telah mengambil peran penting untuk memajukan perempuan di segala bidang sebagaimana tertera dalam pasal 28 ayat 1 UUD 1945 tentang Hak Asasi Manusia yang menyatakan setiap orang berhak mengembangkan diri melalui pemenuhan kebutuhan dasarnya, mendapatkan pendidikan dan memperoleh manfaat dari ilmu pengetahuan dan teknologi, seni serta budaya serta meningkatkan mutu hidup dan kesejahteraan umat manusia. Landasan hulum lain yang memastikan terciptanya kesetaraan gender adalah UU No.7 tahun 1984 tentang pengesahan Konvensi mengenai penghapusan segala bentuk diskriminasi terhadap perempuan dan Instruksi Presiden No.9 tahun 2000 tentang pengarusutamaan gender dalam kebijakan, program dan kelembagaan termasuk bidang pendidikan. Lebih khusus lagi UU No.20 tahun 2003 tentang sistem pendidikan nasional juga telah membuat beberapa paradigma baru yang lebih memberikan kesempatan seluas-luasnya bagi laki-laki dan perempuan untuk berpartisipasi dalam pendidikan.

Kesetaraan gender menjadi suatu program dan kegiatan yang diharapkan dapat meningkatkan derajat dan martabat baik perempuan dan laki-laki. Gender di era global berkaitan dengan kesadaran, tanggung jawab laki-laki, pemberdayaan perempuan termasuk hal reproduksi.

Kesetaraan gender sebagaimana dijelaskan di atas mencakup pula kesetaraan dalam pendidikan secara yuridis, dan kesetaraan tersebut dapat dilihat dalam ketentuan UU No. 20 Tahun 2003 tentang Sistem Pendidikan Nasional: "Pendidikan adalah usaha sadar dan terencana untuk mewujudkan suasana belajar dan proses belajar dan proses pembelajaran agar peserta didik secara aktif mengembangkan potensi dirinya untuk 
memiliki kekuatan spiritual keagamaan, pengendalian diri, kepribadian, kecerdsan, akhlak mulia serta ketrampilan yang diperlukan dirinya masyarakat, bangsa dan negara" (Ayat 1).

Pada pasal di atas menjelaskan bahwa adanya persamaan hak untuk memperoleh pendidikan baik bagi penduduk laki-laki maupun perempuan, selaian itu dalam UUD 1945 terutama dalam pasal 31 ayai 1 juga menyebutkan bahwa, "Setiap warga negara berhak mendapatkan pendidikan. Penjelasan Pasal tersebut mengandung makna bahwa setiap warga negara baik laki-laki maupun perempuan memiliki kesempatan yang sama untuk memperoleh pendidikan sehingga tidak boleh dan dilarang adanya tindakan diskriminasi baik pada laki-laki maupun pada perempuan dengan tujuan agar tercipta kesetaraan gender dalam bidang pendidikan.

tanggung jawab laki-laki, pemberdayaan perempuan termasuk hal reproduksi.

Kesetaraan gender sebagaimana dijelaskan di atas mencakup pula kesetaraan dalam pendidikan secara yuridis, dan kesetaraan tersebut dapat dilihat dalam ketentuan UU No. 20 Tahun 2003 tentang Sistem Pendidikan Nasional: "Pendidikan adalah usaha sadar dan terencana untuk mewujudkan suasana belajar dan proses belajar dan proses pembelajaran agar peserta didik secara aktif mengembangkan potensi dirinya untuk memiliki kekuatan spiritual keagamaan, pengendalian diri, kepribadian, kecerdsan, akhlak mulia serta ketrampilan yang diperlukan dirinya masyarakat, bangsa dan negara" (Ayat 1).

Pada pasal di atas menjelaskan bahwa adanya persamaan hak untuk memperoleh pendidikan baik bagi penduduk laki-laki maupun perempuan, selaian itu dalam UUD 1945 terutama dalam pasal 31 ayai 1 juga menyebutkan bahwa, "Setiap warga negara berhak mendapatkan pendidikan. Penjelasan Pasal tersebut mengandung makna bahwa setiap warga negara baik laki-laki maupun perempuan memiliki kesempatan yang sama untuk memperoleh pendidikan sehingga tidak boleh dan dilarang adanya tindakan diskriminasi baik pada laki-laki maupun pada perempuan dengan tujuan agar tercipta kesetaraan gender dalam bidang pendidikan.

Perhatian terhadap wacana gender utamanya di Indonesia dapat dikatakan relatif masih baru dan semakin berkembang dengan meningkatnya kesadaran kaum perempuan akan harkat kemanusiannya yang karena adanya tekanan dari akar 
budaya patriarki yang banyak diterapkan di berbawai wilayah di Indonesia. Dalam budaya patriarki hak-hak asasi manusia menjadi berkurang bahkan ada yang hilang sama sekali. Dalam beberapa tahun terakhir ini kajian masalah perempuan dan gender di Indonesia menunjukkan perkembangan yang cukup pesat sekaligus merefleksikan meningkatnya kesadaran berbagai kalangan termasuk kalangan yang bergerak dalam dunia pendidikan.

Pendidikan responsif gender dapat diselipkan melalui kurikulum yang responsif gender, sehingga ada bentuk perhatian terhadap hak-hal laki-laki maupun perempuan. Karena pendidikan berperspektif gender tidak hanya untuk perempuan saja tetapi juga untuk laki-laki. Di dalam kurikulum tersebut tertuang kesetaraan gender dalam aktivitas pembelajaran anak-anak sehari-hari, selain itu juga perlu adanya kesetaraan perlakuan pada semua peserta didik di dalam kelas maupun di luar kelas, termasuk perlakuan adil dalam proses pembelajaran. Dalam hal ini pemerintah sudah seharusnya mendukung kesetaraan gender dengan menyusun peraturan perundang-undangan yang berpihak pada kesetaran gender khusunya dalam bidang pendidikan. Harapan-harapan tersebut belum sepenuhnya terwujud dalam dunia pendidikan. Masih terdapat banyak kesenjangan antara laki-laki dan perempuan dalam dunia pendidikan. Untuk itulah diperlukan pendidikan responsif gender.

\section{METODE PENELITIAN}

Penelitian ini termasuk kedalam jenis penelitian tindakan kelas (PTK). Penelitian ini dilakukan di SMAIT Nur Hidayah Sukoharjo pada kelas XII IPS 3, dengan jumlah peserta didik sebanyak 24 siswi sebagai subjek penelitiannya. Kelas XII IPS 3 ini menjadi subjek penelitian dikarenakan, terdapat masalah yang ditemukan pada saat pembelajaran daring melalui Learning Management System yaitu hasil belajar peserta didik yang tidak dapat maksimal. Penelitian tindakan kelas mencoba memberikan solusi untuk memecahkan masalah yang terjadi di dalam kelas saat proses pembelajaran berlangsung. Adapun dalam penelitian ini peneliti mencoba untuk memperbaiki proses belajar daring pada Learning Management System berbasis moodle guna meningkatkan hasil belajar peserta didik. Penelitian ini direncanakan dalam bentuk bersiklus, yang setiap siklusnya masingmasing dilaksanakan dengan empat tahap, yaitu: 1) tahap perencanaan, 2) tahap pelaksanaan, 3) tahap obesrvasi dan 4) tahap refleksi.

Data penelitian ini berupa data kualitatif dan data kuantitatif yang diperoleh secara tes dan non tes. Teknik tes meliputi tes tertulis dan menghasilkan data 
kuantitatif berupa hasil kuis posttest. Sedangkan non tes melalui kegiatan observasi dan dokumentasi (berupa screen record dari aktivitas diskusi perseta didik pada forum diskusi di LMS). Untuk menentukan ketercapaian tujuan perlu dirumuskan indikator keberhasilan tindakan yang disusun secara realistis. Keberhasilan penelitian tindakan kelas ini di indikator adanya peningkatan hasil belajar siwa dalam mata pelajaran sosiologi di dalam kelas. Keberhasilan pembelajaran mata pelajaran sosiologi dilihat dari batas nilai $\mathrm{KKM}$ yaitu 70, dengan menerapkan model pembelajaran discovery learning pada Learning Management System berbasis moodle, diharapkan mencapai presentase yakni:

\begin{tabular}{|l|c|l|}
\multicolumn{3}{|c|}{ Tabel 2. Indikator kinerja penelitian } \\
\hline Variable yang diukur & $\begin{array}{l}\text { Presentase } \\
\text { target capaian }\end{array}$ & Cara mengukur \\
\hline $\begin{array}{l}\text { Hasil belajar } \\
\text { peserta didik siklus I }\end{array}$ & $70 \%$ & $\begin{array}{l}\text { Dihitung dari rata-rata perolehan nilai peserta } \\
\text { didik setelah mengerjakan soal postest }\end{array}$ \\
\hline $\begin{array}{l}\text { Hasil belajar } \\
\text { peserta didik siklus 2 }\end{array}$ & $70 \%$ & $\begin{array}{l}\text { Dihitung dari rata-rata perolehan nilai peserta } \\
\text { didik setelah mengerjakan soal postest }\end{array}$ \\
\hline
\end{tabular}

Indikator kinerja yang ingin diperoleh dalam penelitian tindakan kelas ini adalah meningkatnya hasil belajar Sosiologi pada peserta didik kelas XII IPS 3 di SMAIT Nur Hidayah, setelah menerapkan model pembelajaran discovery learning pada pembelajaran daring di Learning Management System. Sebagai ukuran keberhasilan pelaksanaan penelitian tindakan kelas ini adalah peserta didik yang nilainya mencapai KKM yaitu 70 dan persentase ketuntasan prosentase mencapai lebih dari 70\%. Jika hasil belum memuaskan akan dilakukan siklus II begitu seterusnya. Siklus akan berhenti jika hasil peserta didik sudah memenuhi KKM dan persentase ketuntasan yaitu 70\%. Data yang didapat dalam penelitian ini adalah data kuantitatif yaitu skor hasil belajar peserta didik pada kegiatan pembelajaran siklus I dan siklus II.

Analisis dalam penelitian tindakan kelas dimulai sejak awal sampai berakhirnya pengumpulan data. Hal ini penting karena akan membantu peneliti dalam mengembangkan penjelasan dari kejadian atau situasi yang berlangsung didalam kelas yang diteliti. Data-data dari hasil penelitian di lapangan diolahsecara analisis kualitatif yang mengacu pada model analisis Eliot menurut Takari (2008: 29) yang dilakukan dalam tiga komponen, yaitu:reduksi data, paparan data, dan penyimpulan.

\section{HASIL}

Penelitian tindakan kelas ini diterapkan pada pembelajaran daring melalui Learning Management System berbasis moodle mata pelajaran sosiologi di 
kelas XII IPS 3 pada materi globalisasi. Pelaksanaan penelitian tindakan kelas dilakukan 2 siklus. Siklus I dilakukan 2 pertemuan dan siklus II dilakukan 1 pertemuan. Rangkaian siklus I ditemukan kendala-kendala sehingga tujuan penelitian belum dapat terlaksana. Oleh sebab itu, diadakan rangkaian siklus kedua dengan harapan siklus kedua dapat mewujudkan tujuan penelitian dengan belajar menganalisis kendala-kendala yang ditemui pada siklus pertama. Dalam penelitian ini siklus kedua tujuan hasil penelitian sudah dapat terwujud maka penelitian dapat dihentikan.

\section{Kondisi Pra Siklus}

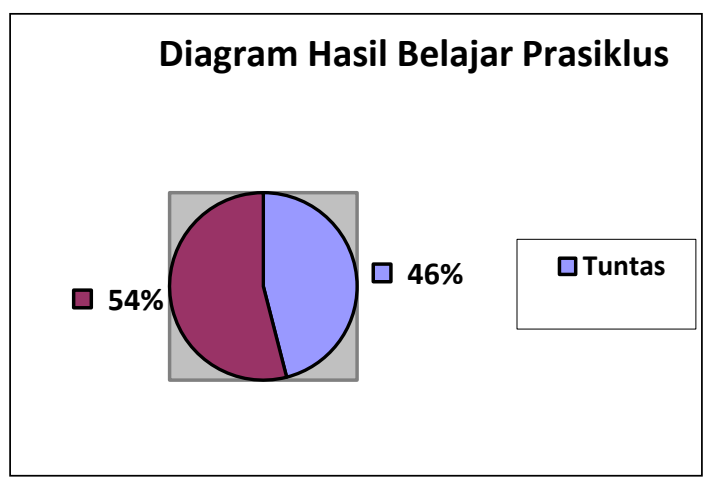

Gambar 3.1. Diagram Hasil Belajar Prasiklus

(Sumber: Data Peneliti, 2020:6)

Dari gambar di atas diperoleh bahwa hasil belajar peserta didik masih rendah, peserta didik yang telah memenuhi Kriteria Ketuntasan Minimal (KKM) sebanyak 12 peserta didik dari 26 peserta didik, bila diprosentasekan sebesar $46 \%$. Peserta didik yang tidak memenuhi batas
KKM yaitu 14 siswi sebesar 54\%. Rata-rata kelas yang diperoleh peserta didik pada penilaian PTS Gasal sebesar 68.

\section{Tindakan Siklus I}

Setelah dilakukan tindakan pada siklus I dengan penerapan model Discovery Learning berbasis moodle dapat dilihat perbandingan hasil belajar peserta didik pada tabel berikut.

Tabel 3.2

\section{Perbandingan Hasil Belajar Prasiklus dan Siklus I}

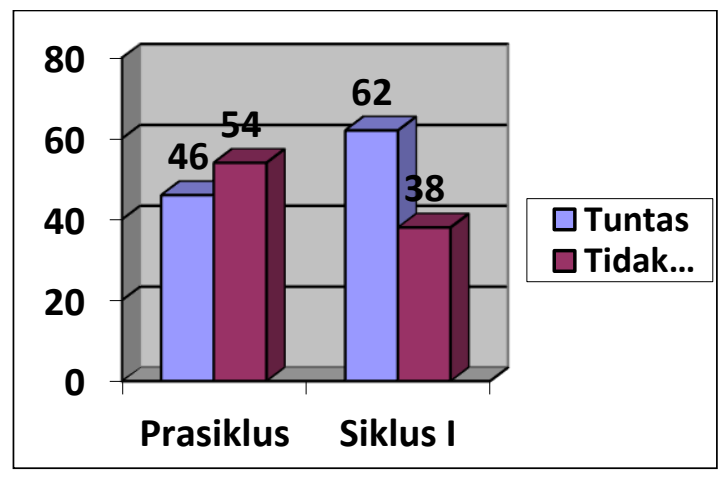

(Sumber: Data Peneliti, 2020:7)

Berdasarkan gambar diatas, penerapan model Discovery Learning pada siklus I menunjukkan bahwa ketuntasan peserta didik mencapai KKM berjumlah 16 peserta didik (62\%), sedangkan peserta didik yang belum memenuhi KKM sebanyak 10 peserta didik (38\%). Nilai rata-rata yang diperoleh peserta didik dalam penerapan disiklus I adalah 73 . Dengan demikian dapat diketahui setelah penerapan discovery learning hasil belajar 
peserta didik mengalami peningkatan pada prasiklus yaitu $16 \%$ namun, belum menunjukkan hasil seperti yang ditetapkan peneliti. Berdasarkan hasil analisis yang telah dilakukan oleh peneliti, dapat diketahui bahwa masih terdapat beberapa kelemahan yang terjadi baik dari guru maupun peserta didik, sehingga guru dan peserta didik memutuskan untuk melakukan siklus II.

\section{Tindakan Siklus II}

Tindakan siklus II dilakukan untuk lebih meningkatkan hasil belajar peserta didik pada siklus I. Setelah dilakukan tindakan pada siklus II dengan penerapan model Discovery Learning berbasis moodle dapat dilihat perbandingan hasil belajar peserta didik pada tabel berikut.

Tabel 3.3

Perbandingan Hasil Belajar Pras Siklus, Siklus I dan Siklus II

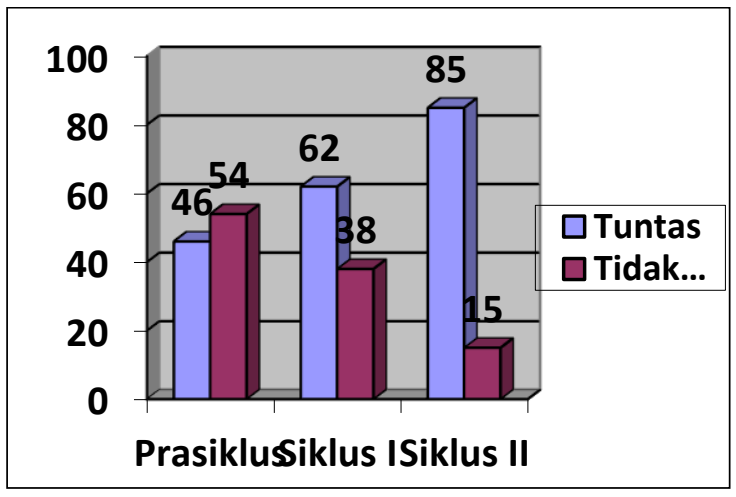

(Sumber: Data Peneliti,2020:8)
Berdasarkan gambar diatas dapat diketahui bahwa dengan penerapan model discovery learning dapat diuraikan bahwa terjadi peningkatan hasil belajar dalam aspek kognitif peserta didik kelas XII IPS 3 dilihat dari jumlah peserta didik yang berhasil melewati Kriteria Ketuntasan Minimal, yaitu 70. Dari kegiatan awal prasiklus sebelum penerapan discovery learning jumlah peserta didik yang melewati KKM sebanyak 12 peserta didik dengan presentase $46 \%$. Setelah penerapan model discovery learning pada siklus I, jumlah peserta didik yang melewati KKM menjadi 16 peserta didik dengan presentase $62 \%$, dan pada siklus II terjadi lagi peningkatan hasil belajar sebanyak 22 peserta didik dengan presentase $85 \%$.

Berdasarkan observasi yang telah dilakukan dan hasil yang telah didapatkan maka dapat disimpulkan oleh peneliti bahwasanya model discovery learning dapat meningkatkan hasil belajar kognitif peserta didik kelas XII IPS 3 Nur Hidayah Sukoharjo.

\section{DISKUSI}

Pelaksanaan pembelajaran model Discovery Learning mampu meningkatkan hasil belajar karena memberikan kesempatan penuh bagi peserta didik untuk menjadi pembelajar yang aktif dan 
menemukan pengetahuan yang dimilikinya melalui kegiatan diskusi dan presentasi kelompok. Hal ini sejalan dengan pendapat J. Bruner yang mengatakan bahwa anak harus berperan secara aktif didalam belajar di kelas. Untuk itu Bruner memakai cara dengan apa yang disebutnya discovery learning, yaitu dimana murid mengorganisasikan bahan yang dipelajari dengan suatu bentuk akhir. Bruner menganggap bahwa belajar penemuan sesuai dengan pencarian pengetahuan secara aktif oleh manusia, dan dengan sendirinya memberi hasil yang paling baik. Berusaha sendiri untuk mencari pemecahan masalah sera pengetahuan yang menyertainya, menghasilkan pengetahuan yang benar-benar bermakna (Ratna Wilis Dahar (2006:79).

Penggunaan model discovery learning ini bertujuan untuk meningkatkan aktivitas siswa dalam proses belajar mengajar. Model pembelajaran discovery learning mampu membantu siswa untuk mengembangkan, memperbanyak kesiapan, serta penguasaan keterampilan dalam proses kognitif/pengenalan siswa. Siswa memperoleh pengetahuan yang bersifat sangat pribadi individual sehingga dapat kokoh/mendalam tertinggal dalam jiwa siswa tersebut. Selain itu, model ini mampu membangkitkan kegairahan belajar mengajar para siswa dan membantu siswa untuk memperkuat dan menambah kepercayaan pada diri sendiri dengan proses penemuan sendiri. Strategi itu berpusat pada siswa tidak pada guru. Guru hanya sebagai teman belajar saja atau sebagai fasilitator, membimbing siswa dalam kegiatan belajar mengajar. Oleh karena itu, pembelajaran dengan model Discovery Learning menjadi efektif dalam membentuk pengetahuan peserta didik dengan menemukan pengetahuannya sendiri sehingga menjadikan peserta didik aktif dalam proses pembelajaran.5.

\section{KESIMPULAN}

Berdasarkan hasil penelitian yang telah dilakukan, dapat diambil kesimpulan: (1) pendekatan saintifik dengan model pembelajaran discovery learning dapat memberikan respons positif dalam proses pembelajaran pada materi globalisasi melalui sintaks-sintaks discovery learning ; dan (2) pendekatan saintifik dengan model pembelajaran discovery learning dapat meningkatkan hasil belajar peserta didik Kelas XII IPS 3 SMAIT Nur Hidayah Sukoharjo pada materi globalisasi dan permasalahan akibat globalisasi. Hal tersebut terlihat dari meningkatnya hasil post test peserta didik. Pada siklus I ratarata kelasnya 68 dengan persentase ketuntasan belajar $62 \%$ dan pada siklus II rata-rata kelasnya 83 dengan persentase ketuntasan $85 \%$. 


\section{Daftar Pustaka}

Arikunto, Suharsimi, dkk. (2010). Penelitian Tindakan Kelas. Jakarta: Bumi Aksara.

Huda, Miftahul. (2013). Model-model Pembelajaran dan Pembelajaran. Yogyakarta : Pustaka Pelajar.

Eliot 1982 dalam Drs. Tatang Sunendar, M.Si. Penelitian Tindakan Kelas (16 April 2016).

Ishmah (2018). "Penerapann model discovery learning untuk meningkatkan hasil belajar matematika siswa kelas VII SMP Labsschool FIP UMJ”. [Online].Tersedia: https://jurnal.umj.ac.id/index.php/fbc/article/view/3371. Diakses pada 13 Oktober 2020.

Novita, Fidya. (2018). "Peningkatan Aktivitas dan Hasil Belajar melalui Model Discovery Learning dengan Pendekatan Saintifik”. [Online]. Tersedia: https://ejournal.unib.ac.id/index.php/jppb/article/view/6811. Diakses pada 13 Oktober 2020. Diakses pada 13 Oktober 2020.

Rosarina, Gina., Sudin, Ali., dan Sujana, Atep. (2016). Penerapan Model Discovery Learning Untuk Meningkatkan Hasil Belajar Siswa Pada Materi Perubahan Wujud Benda. Jurnal Pena Ilmiah. 1(1):371-380.

Roza, Nitia (2018). "Practicality Of Mathematics Learning Tools Based On Discovery Learning For Topic Sequence And Series". [Online]. Tersedia: https://www.ijstr.org/final-print/may2018/Practicality-Of-Mathematics-LearningTools-Based-On-Discovery-Learning-For-Topic-Sequence-And-Series.pdf. Diakses pada 13 Oktober 2020.

Sundari, Sri Gening (2018). "Peningkatan hasil belajar biologi dengan model discovery learning”. [Online]. Tersedia: https://doi.org/10.31539/bioedusains.v1i2.449. Diakses pada 13 Oktober 2020.

Warda, Anisa dan Sudibyo, Elok. (2018). Keterampilan Berpikir Kritis Siswa dalam Implementasi Model Discovery Learning pada Sub Materi Pemanasan Global. E- Journal Pensa. 06 (02):238-242.

Wiriaatmadja, Rochiati. (2012). Metode Penelitian Tindakan Kelas. Bandung: PT Remaja Rosdakarya. 